BELIEVING WOMEN IN ISLAM 
This page intentionally left blank. 


\title{
Believing
}

\section{WOMEN IN \\ Islam}

\section{A Brief Introduction}

\author{
ASMA BARLAS \\ DAVID RAEBURN FIN N
}


Copyright () 2019 by the University of Texas Press

All rights reserved

Printed in the United States of America

First edition, 2019

Requests for permission to reproduce material

from this work should be sent to:

Permissions

University of Texas Press

P.O. Box 78 I 9

Austin, TX 78713-7819

utpress.utexas.edu/rp-form

The paper used in this book meets the minimum requirements of ANSI/NISO Z39.48-I992 (RI997) (Permanence of Paper). ()

Library of Congress Cataloging-in-Publication Data

Names: Barlas, Asma, author. | Finn, David Raeburn, author.

Title: Believing women in Islam : a brief introduction /

Asma Barlas and David Raeburn Finn.

Description: First edition.

Austin : University of Texas Press, 2019.

Includes bibliographical references and index.

Identifiers: LCCN $201802375 \mathrm{I}$

ISBN 978-I-4773-I 588-o (pbk. : alk. paper)

ISBN 978-I-4773-I 589-7 (library e-book)

ISBN 978-I-4773-I 590-3 (non-library e-book)

Subjects: LCSH: Women in the Qur'ān. | Women in Islam.

Women's rights-Religious aspects-Islam.

Qur'ān-Criticism, interpretation, etc.

Qur'ān-Theology.

Classification: LCC BPI34.W6 в28 520 I 8 | DDC 297.I/2283054-dc23

LC record available at https://lccn.loc.gov/20 I 802375 I

doi: $10.7560 / 315880$ 